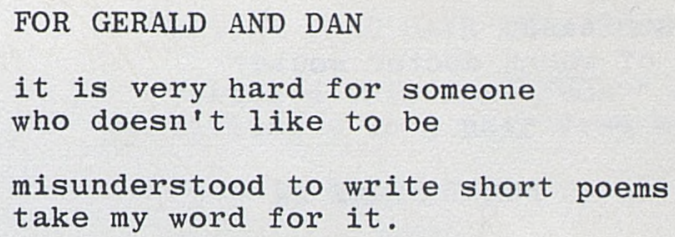

Fresno CA

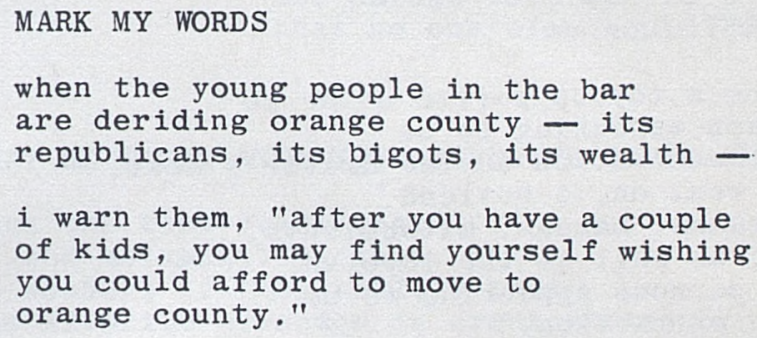

\title{
MITIGATING CIRCUMSTANCES
}

a woman who overhears me say that my daughter's first child was delivered by a midwife says,

"i would imagine that you must have been concerned by that."

"you would imagine otherwise," i say," "if you knew my opinion of the medical profession."

\section{THE FRYING PAN AND THE FIRE}

a bright young female friend of mine writes me, concerning gynecologists,

"what sort of man would want to look up

a woman's skirts all day every day?"

i see what she means. 
on the other hand, what sort of woman doctor would?

\section{DON'T $^{\prime}$ BLAME ME}

a newsletter just arrived from women's studies and, honest-to-god, the lead article is entitled

"busy beavers."

\section{AMERICA FIRST}

this morning a toyota pulled aside me with a person appearing to be of japanese extraction in the driver's seat. as the day went on, i noticed hondas, nissans, mazdas, mitsubishis, and isuzus, as well as the toyotas, piloted by persons appearing to be of japanese extraction. why aren't these people driving american cars? I wondered. they are americans now - why are they supporting the economy of their ancestors?

after all, $i$ don't drive an irish car. i drive a korean car.

NO WONDER THE ARABS WEAR ROBES

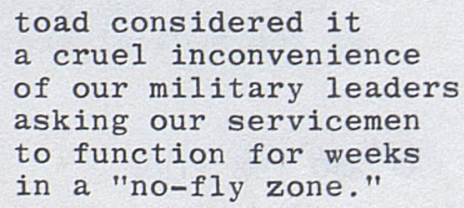

HE DIDN'T FEEL A DAY OVER EIGHTY-NINE

the plague cut short the careers of many major talents of the sixteenth century, giorgione, for instance, dead in his thirties, and titian, snuffed at ninety. 